\title{
Measuring and Improving Service Quality in The Context of a Higher Educational Institution: Human Science Students' Perceptions at Sariputta College, Muse, Northern Shan State, Myanmar
}

\author{
Nyar Ti Ka
}

Master of Management in Organization and Development (MMOD), Master of Philosophy and Religion (candidate), Faculty of Graduate School of Business, Assumption University, Bangkok, Thailand

\begin{tabular}{l} 
ARTICLE INFO \\
\hline Keywords: \\
Quality management \\
Higher education \\
Private nonprofit college \\
Five SERVQUAL dimensions \\
of service quality \\
SWOTAR analysis \\
Multiple liner regression \\
One-way ANOVA
\end{tabular}

\section{Introduction}

Service quality was first developed as an economic factor in the early 1980s; the service quality is a relationship between effects and progress in which effects are achieved. Hence, the origin of development in education is a service quality of management and is considered as a systematic requirement for management change in education (Frasier, 1997) as the commercial organizations confront unceasingly demand to satisfy clients. Similarly, educational institutions also need to consider their students by offering superior service quality at their school (Srikanthan and Dalrymple, 2007). Thus, to become a successful educational institution,

\begin{abstract}
The main purpose of this research is to determine the current situation of the five SERVQUAL dimensions of service quality instrumentation: tangibles, reliability, responsiveness, assurance, and empathy. These dimensions are used shed light on the most meaningful service features. This study has used a service quality model from an undergraduate student's point of view. It aimed to explore and evaluate current service attitude and quality at the college. A mixed methodology was conducted on human science program students at Sariputta College in 2019. The students were selected through printed questionnaires using the purposive sampling method. The students' attitude towards educational service quality was measured through a questionnaire that was designed according to service quality instrumentation based on the five dimensions. The quantitative data was analyzed by SPSS software through the Alpha Test, Descriptive Statistics, Multiple Linear Regression and one-way ANOVA and also by qualitative analysis. The results revealed the lowest recorded service quality gaps belonged to the tangible (-.042) and the highest belonged to the empathy (.007) dimensions respectively. Moreover, a significant number of students felt that Sariputta College does not have an up-to-date curriculum and the highest number felt that the staff of Sariputta College are friendly towards them. Another factor that emerged concerned the facilities and equipment which need to be upgraded in order to reduce the undergraduate students' negative attitude towards higher education at the college. Thus, it is recommended that services are provided based on students' needs and suggestions.
\end{abstract}

* Corresponding Author E-Mail Address: nyartikham@gmail.com 
the schools need to remember their unremitting efforts to protect school service quality. (Kwek, Lau, and Tan, 2010); Chong \& Ahmed, 2012).

\section{Related Concepts Literature Review}

In this research, the service quality for education mainly applied the SERVQUAL model, which was developed by Parasuraman, Zeithaml, \& Berry (1985), as the judgment of customers approach to the service.

In this research, the service quality for education mainly applied the SERVQUAL model, which was developed by Parasuraman, Zeithaml, \& Berry (1985), as the judgment of customers approach to the service. Zeithaml, Berry \& Parasuraman (1996;2003) mentioned that service quality is a focused evaluation that reflects the customer's perception of specific measurement of service namely tangibles, assurance, empathy, reliability and responsiveness. Based on the assessment of service quality provided to the customers, business operators can identify issues quickly, improve their service, and better assess client expectation. On the other hand, (Kotler, 1996); and Ramaswamy (1996, p. 3) thought-about service as "the business transactions that ensue between a service provider and receiver (customer) to supply an effect that satisfies the client." Outlined service as "deeds, performances, and processes" Zeithaml and Bitner (1996, $\mathrm{p}$.5) developed that service quality is one of the managements that has the potential of developing. The Service of education that uses service action to enhance success to measure customers' satisfaction in evident appearance. The service management to reduce un-satisfy at least possible. Education institute from nursery school level to university is one of essential service for institution. However, different scholars have explicit that service quality has been mixed as having strong positive relationships.

\subsection{Background of the Sariputta College}

In Myanmar, private higher educational institutions have appeased and grow up both in States and divisions. These college are run by Nonprofit organization. One of the religious colleges is the Sariputta College which is the subject of this paper. Sariputta was founded by Venerable Visuddha, in April 2013. It's a non-profit higher education institution located in the center of Muse township, northern Shan State, Union of Myanmar. Muse town is developed by Shan Nationals and Shan Chinses, majority of them being a Buddhist and Christion. it is a busy border economic cooperation core zones with China.

From 1967 to 2012, the Sariputta college initially started running as a monastic education housing over 100 of young novice monks who traveled from all parts of Shan State in pursuit of education. The college later upgraded to the status of school under close consultation with Ven. Dr. Khammai Dhammasami, head of Oxford Buddha-vihara, lecture of Oxford University UK. The title of "Sariputta College" was additionally given by him to honor the works of Ven. Sariputta, one among the great disciples of Buddha throughout His life. Ven. Sariputta was highly appreciated by Buddha Himself because of the wisest amongst his disciples.

In May 2013, the college started admitting its first batch of students by providing a two years' diploma program in Buddhist Studies for students who completed advanced level from the Sangha school running within the temple, and began admitting outside students who succeed higher monastic qualifications and "O" level from state-run education faculties attentiongrabbing in the program. However, in 2015, Sariputta, started providing Bachelor of Arts 4year program in Human Science Studies. (Mahapanya 2017)

In this study, the researcher employs SWOTAR Strengths, Weakness, Opportunities Threats, Aspirations, and Results analyses as the tools to initially explain the current situation of the organization. The analyses are drawn from the initial discussion with a group of management, document reviews, and participant observation. The SWOTAR analyses of service quality at Sariputta College is shown as Table 1, below: 
Table 1.

SWOTAR Analysis of Service Quality

\begin{tabular}{|c|c|}
\hline $\begin{array}{l}\text { 1) Strengths } \\
\text { - A solid team of staff who are willing to learn } \\
\text { - Good collaboration among stakeholders } \\
\text { - Highly accredited by the Buddhist community from } \\
\text { both local and abroad } \\
\text { - Privately run college } \\
\text { - Highly motivated students from different religious } \\
\text { backgrounds }\end{array}$ & $\begin{array}{l}\text { 2) Weaknesses } \\
\text { - Lack of capacity development training on providing } \\
\text { quality service } \\
\text { - Limited communication between staff and students } \\
\text { - Limited budget } \\
\text { - Very few staff members } \\
\text { - Need to improve channels to connect with students } \\
\text { - Lack of qualified local resources }\end{array}$ \\
\hline $\begin{array}{l}\text { 3) Opportunities } \\
\text { - Reflect and improve the provision of service quality } \\
\text { - Upgrade as a university in the future } \\
\text { - More and more students are joining the college } \\
\text { - Located at China and Myanmar border }\end{array}$ & $\begin{array}{l}\text { 4) Threats } \\
\text { - Financially not supported by Myanmar Government } \\
\text { - Highly rely on donor } \\
\text { - Highly depend on visiting professors from abroad }\end{array}$ \\
\hline $\begin{array}{l}\text { 5) Aspirations } \\
\text { - To improve the provision of quality service by all } \\
\text { staff and tutors } \\
\text { - To improve a better relationship between students } \\
\text { and staff } \\
\text { - To improve college image }\end{array}$ & $\begin{array}{l}\text { 6) Results } \\
\text { - Staff will become qualified ones who are fully } \\
\text { aware of how to provide the best service quality. } \\
\text { - The number of qualified local staff will increase }\end{array}$ \\
\hline
\end{tabular}

\subsection{SWOTAR Analysis of Service Quality}

\subsubsection{Strengths}

Sariputta College has a solid team of staff who are motivated and willing to improve their capacity. In this case, the researcher believes that they are ready to provide a better quality of service and serve to their best to all students particularly. It also has a strong collaborative team of senior officers who has a strong connection with stakeholders (donor) from local and abroad. Some stakeholders (donor) are from UK, Australia, and the USA, and they are willing to help to improve the quality of service upon request. Sariputta College is a private college run by a Buddhist community in Muse township, Myanmar. As a private college, they have the autonomy to decide their curriculum, instructional strategies, assessments, admission policy, and program design. The college asked a very little amount of tuition fee from students, and it also receives donation money from donors. This college is highly accredited and supported by the Buddhist community, venerable abbots and monks from not only Myanmar but also from China. The graduates from the college can find a decent job after school, and they can also continue further studies in China and other places. The population of students is comprised of monks, nuns, and layman from a different religious background. The school environment is diverse in terms of ethnicities, religions, and social background. This creates an opportunity for students to learn from each other, to understand multi-culture, to respect, and to live in harmony. Most of the students are vulnerable individuals with less opportunity to study quality education, but they are very highly motivated to pursue education and attentive to their lessons.

\subsubsection{Weaknesses}

Most of the staff do not receive capacity development training. The communication with students is very straight forward and it was reported that students sometimes are not satisfied with the service they received from the staff. It is also revealed that staff takes a long time to finish the tasks, such as the admission process, logistics, general administration, and financing. The college also has a very limited budget for their staff to improve their exposure and capacity. In addition to that, the college has a very few working staff who are sometimes stressed with burdens of work. Looking at the physical environment, the college is equipped with facilities to provide a better learning atmosphere for students. However, there are things needed to do to 
improve the infrastructure to be up to date. For example, the books in the library are old, and the furniture is also not convenient. There is no study room in the library for students to do group works or pair work. The tables, chairs and teaching materials in the classrooms are not modified for a long time, and it needs renovations

\subsubsection{Opportunities}

After this research is carried out, Sariputta College will have opportunities to reflect their current provision of service to students, and they will be able to improve their service quality based on the recommendations obtained from the analysis of research findings. As there is no institution which provides higher education in Muse, Sariputta College is the only choice for local youth. During the past years, the numbers of student who enrolled at the college have increased a lot, and it has become a popular destination for young people to sharpen their academic knowledge and skills. In the future, the college has the vision to upgrade itself to the university, which can provide better quality education for monks, nuns, and all laymen. It is also located at a strategic place, which is at China and Myanmar border. It can be an educational institution which will give services to those scholars and students from Myanmar and China. The cooperation between this college and Chinese universities will benefit many young people in the region.

\subsubsection{Threats}

As Sariputta College is a privately-owned institution, the government do not support any financial means for the school, and they do not interfere in the admission process, management process, teaching, and assessment. Most of the funds are from students, private donors, and the Buddhist community in the region. The college is also relying highly on visiting professors from abroad as it has very limited local professors. Most of the local professors had little exposures about teaching, and some of them are receiving training in another country. As one of the challenges, the colleges are in lack of qualified local resources who can lead and manage the whole school to reach its strategic goals.

\subsubsection{Aspirations}

During the intervention period, the researcher would like to improve the service quality of all staff and tutors because they are the ones who are providing general services to the students. If they know about their roles and responsibilities very well, the service quality also will improve. Also, this intervention will help to improve a better relationship between students and staff. It is expected that the staff will build a friendly, timely, and responsive relationship with all the stakeholders, including students. Finally, the interview would help to create the image of college to be better and more reputable in giving services. During the intervention, the researcher will conduct workshops and training for staff to improve their service quality in terms of reliability, responsiveness, assurance, empathy, and tangibles.

\subsubsection{Results}

The researcher is expecting the following results at the end of this action research. Firstly, the staff will become qualified, and they are fully aware of how to provide the best service quality. Secondly, there will be an increasing number of qualified local staff who know very well about building a good relationship with students.

\subsection{The Research Problem}

The Sariputta College is situated remote place of the country that is have not yet developed satisfactorily. The Sariputta College's service quality is not yet satisfactorily as seen by SWOTAR. 


\subsection{Research Questions}

1. What is the current situation of service quality in terms of reliability, responsiveness, assurance, empathy, and tangibles at Sariputta College?

2. What are the factors influencing on the service quality of Sariputta College?

3. What is the appropriate OD intervention that can improve the service quality in terms of assurance, empathy, reliability, responsiveness, and tangibles at Sariputta College?

\subsection{Definitions of variables Terms Used in the Research}

Service Quality: can be defined as organization regularly evaluate the service quality support to their customers in order to improve their service, to quickly describe issues, and to better performance and meaningful service for client. Zeithaml, Berry \& Parasuraman (2003).

Assurance: refers to the skill, courtesy of staffs and ability to convey trust and confidence with students. Zeithaml, Parasuraman, and Malhotra (2003).

Empathy: refers to the provision of caring, individualized attention provided to students. Ziethaml et al., (2003)

Reliability: refers to the ability to perform the promised service dependably and accurately. Ziethaml et al., (2003)

Responsiveness: is defined to the willingness to help students and to provide prompt service towards the service provider. Ziethaml et al., (2003)

Tangibles: refers to the appearance of physical facilities, equipment, personnel, and communication materials. Ziethaml et al., (2003)

\subsection{Conceptual Framework}

Theory foundation of this research: According to Mbise and Tuninga (2012) in their Service Quality SERVQUAL model, they have developed six dimensions showing significance to the measure of service quality, particularly (a) tangibles, (b) reliability, (c) responsiveness, (d) assurance (e) empathy and (f) process outcome. The purpose of this research, an increased approach to exploit Service Quality SERVQUAL is adopted for educational activity service quality, to assign scarce resources properly to create effective investment selections and to enhance quality in higher education. Mbise and Tuninga, developed, and valid SERVQUAL instrument to quantify service quality delivered to students at Business school. At the same time, the researcher used the methodology a longitudinal survey is conducted with handily elect students in their final year of study from two business colleges in an emerging economic system. The research is investigated on the SERVQUAL model procedures for developing a reliable and valid multi-item instrument are determined. Pre-testing of the instrument has been conducted before it is administered to the sampled population. In this study, the researcher found that the students' gap scores on observed educational services from an emerging economy are bestowed.

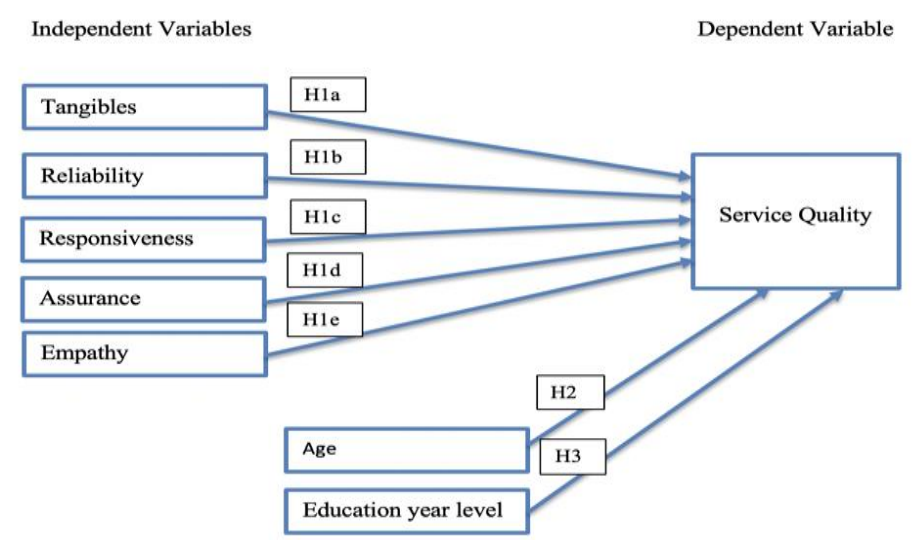

Figure 1. Modified Research Conceptual Framework based on theoretical Framework 


\section{Research Methodology}

The researcher administered with a mixed method of qualitative and quantitative data collection methodologies for this research study. The adapted version of SERVQUAL service quality, modified by Mbise and Tuninga (2012), was administered to determine overall service quality at Sariputta College. For a qualitative approach, the researcher developed three open questions in which students wear asked to tell about their perception toward service quality at Sariputta College. The quantitative questionnaires were distributed to all the students who were studying at Sariputta College during the academic year of 2019. Therefore, the researcher collects the data from 80 students. On the other hand, six of the students were randomly selected to answer qualitative questions. Following the data collection process, the statistical analysis was conducted, and hypotheses were tested by SPSS analyzed multiple linear regression, and one-way ANOVAa.

The researcher used observation, quantitative questionnaires, and qualitative questions to determine students' perception of service quality at Sariputta College. In the quantitative research instrument, two parts were comprised, (1) demographic profile of the students to provide their gender, age, and education year level, and (2) dimensions of Service Quality: For the service quality in terms of responsiveness, assurance, tangibles, reliability, and empathy, students were asked to express their perception with 5 Point Likert Scale as below: Strongly disagree, disagree, neutral, agree and strongly agree.

\section{The Result of Hypotheses Testing}

4.1. Hypothesis 1a-1e: Analysis of the influence of the tangibles, reliability, responsiveness, assurance, and empathy on service quality.

H1ao: Tangibles have no significant influence on service quality.

H1aa: Tangibles have a significant influence on service quality.

$\mathrm{H} 1 \mathrm{~b}_{\mathrm{o}}$ : Reliability has no significant influence on service quality.

$\mathrm{H} 1 \mathrm{~b}_{\mathrm{a}}$ : Reliability has a significant influence on service quality.

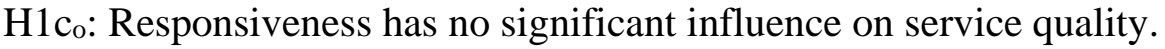

H1ca: Responsiveness has a significant influence on service quality.

H1d $\mathrm{d}_{\mathrm{o}}$ Assurance have no significant influence on service quality.

H1d $_{\mathrm{a}}$ Assurance has a significant influence on service quality.

H1e : Empathy has no significant influence on service quality.

H1e: Empathy has a significant influence on service quality.

Table 2.

Multiple Linear Regression Model Summary of Hypotheses 1 Model Summary

\begin{tabular}{ccccc}
\hline Model & $\mathrm{R}$ & $\mathrm{R}$ Square & Adjusted R Square & Std. Error of the Estimate \\
\hline 1 & $.825^{\mathrm{a}}$ & .681 & .660 & .24211 \\
\hline
\end{tabular}

a. Predictors: (Constant), EMP, ASSU, REP, RELI, TGL

Based on Table 2 the researcher found that the Correlation Coefficient (R) is 0.825 . This result shows that the tangibles, reliability, responsiveness, assurance, and empathy have a strong relationship on service quality. Also, $\left(\mathrm{R}^{2}\right)$ square is to 0.681 , which can be interpreted that it affects service quality to enhance by $68 \%$ when the tangibles, reliability, responsiveness, assurance, and empathy enhance. 
Table 3.

ANOVA Table for Regression Model of Hypothesis 1

\begin{tabular}{lllllll}
\multicolumn{2}{l}{ ANOVA $^{\mathrm{a}}$} \\
\multicolumn{2}{l}{ Model } & Sum of Squares & $\mathrm{df}$ & Mean Square & $\mathrm{F}$ & Sig. \\
\hline \multirow{2}{*}{1} & Regression & 9.268 & 5 & 1.854 & 31.623 & $0.000^{\mathrm{b}}$ \\
\cline { 2 - 7 } & Residual & 4.338 & 74 & .059 & & \\
\cline { 2 - 7 } & Total & 13.605 & 79 & & & \\
\hline
\end{tabular}

a. Dependent Variable: SQ

b. Predictors: (Constant), EMP, ASSU, REP, RELI, TGL

Based on Table 3 the resulting outcome showed that the significant level is equal to 0.000 , which is less than $0.05(.000<.05)$. The null hypothesis is rejected, and at least one independent variable has an influence on service quality at significant - a level of 0.05 . Therefore, a model of regression is statistically significant.

Table 4.

Summary of Coefficient for Regression Model of Hypothesis 1

Coefficients

\begin{tabular}{|c|c|c|c|c|c|c|}
\hline & \multirow[t]{2}{*}{ Model } & \multicolumn{2}{|c|}{$\begin{array}{l}\text { Unstandardized } \\
\text { Coefficients } \\
\end{array}$} & \multirow{2}{*}{$\begin{array}{c}\text { Standardized } \\
\text { Coefficients } \\
\text { Beta } \\
\end{array}$} & \multirow[t]{2}{*}{$\mathrm{t}$} & \multirow[t]{2}{*}{ Sig. } \\
\hline & & B & Std. Error & & & \\
\hline \multirow[t]{6}{*}{1} & (Constant) & .482 & .364 & & 1.325 & .189 \\
\hline & Tangibles & -.036 & .405 & -.042 & -.090 & .069 \\
\hline & Reliability & .136 & .038 & .170 & .572 & .009 \\
\hline & Responsiveness & .583 & .096 & 627 & 6.079 & .000 \\
\hline & Assurance & .037 & .040 & .061 & .908 & .007 \\
\hline & Empathy & .417 & .076 & .430 & 1.512 & .005 \\
\hline
\end{tabular}

a. Dependent Variable: SQ

Based on Table 4, the regression results described that the significance level of the service quality in term of reliability, responsiveness, assurance, and empathy is less than 0.05 . This means that these independent variables have a significant influence on service quality. Moreover, the beta of standardized coefficients shows Responsiveness at 0.627. Empathy at 0.430 , and reliability at 0.170 , respectively. In contrary, the tangible shows the significance level of 0.069 and the beta of the standardized coefficients at -0.90 . Therefore, the variables got the result of signification level more than 0.05 could be referred that it has no significant influence on the service quality.

4.2. Hypothesis 2: Analysis of the influence of the Age on service quality.

$\mathrm{H} 2_{\mathrm{o}}$ : There are no significant differences among the respondent when classified by age

$\mathrm{H} 2 \mathrm{a}$ : There is significantly different among the respondent when classified by age

Table 5.

One-Way ANOVA Results of Analysis on Hypothesis H2

ANOVA

$\mathrm{SQ}$

\begin{tabular}{lccccc}
\hline & Sum of Squares & df & Mean Square & F & Sig. \\
\hline Between Groups & .236 & 3 & .079 & .446 & .721 \\
Within Groups & 13.370 & 76 & .176 & & \\
Total & 13.605 & 79 & & & \\
\hline
\end{tabular}

According to the table 5 the consequences could be interpreted that there is no significant difference between age level and service quality because of its significant level at 0.721 which 
was more than the significant level at 0.05 . So, the result shown the hypothesis $\mathrm{H} 2{ }_{0}$ : "There is no significant difference between age level and service quality" was failed to reject.

\subsection{Hypothesis 3: Analysis of the Educational year Level on service quality}

$\mathrm{H} 3$ : There is no significant different among the respondent when classified by education level. $\mathrm{H} 3_{\mathrm{a}}$ : There is significant different among the respondent when classified by age education level.

Table 6.

One-Way ANOVA Results of Analysis on Hypothesis H3

ANOVA

SQ

\begin{tabular}{lccccc}
\hline & Sum of Squares & df & Mean Square & F & Sig. \\
\hline Between Groups & .553 & 3 & .184 & 1.073 & .365 \\
Within Groups & 13.052 & 76 & .172 & & \\
Total & 13.605 & 79 & & & \\
\hline
\end{tabular}

According to the table 6 the consequences could be interpreted that there is no significant difference between education level and service quality because of its significant level at 0.365 which was more than the significant level at 0.05 . So, the result shown the hypothesis $\mathrm{H} 3_{\mathrm{o}}$ : "There is no significant difference between education level and service quality" was failed to reject.

\subsection{Summary of Finding}

The researcher distributed a structured questionnaire contained 22 questions to 80 respondents from undergraduate students at Sariputta Collage. Those questions designed into five independent variables, namely tangibles, reliability, responsiveness, assurance, and empathy. The researcher analyzed the highest and lowest means of the intended variables which are shown in the Table 7 and 8.

Table 7.

Summary of the Highest Means Value of Variables

\begin{tabular}{llc}
\hline Variable & Measure & Mean value \\
\hline Assurance & A4: Lecturers of Sariputta College have academic credentials. & 4.44 \\
Tangible & T1: Sariputta College has an up-to-date curriculum. & 4.27 \\
Empathy & E1: Staff of Sariputta College has students' best interest at heart. & 4.27 \\
Reliability & RL1: Sariputta College provide feedback on students' progress. & 4.21 \\
Service quality & SQ2: When Sariputta College commits to providing a service at the scheduled time, it does so. & 4.20 \\
Responsiveness & RP2: The staff of Sariputta College is always available to answer students' requests. & 4.20 \\
\hline
\end{tabular}

Table 8.

Summary of the Lowest Means Value of Variables

\begin{tabular}{lll}
\hline Variable & Measure & Mean value \\
\hline Assurance & A2: The staff of Sariputta College are friendly toward students. & 3.49 \\
Service quality & SQ 4: Staff are willing to give students individual attention. & 4.04 \\
Tangibles & T4: The layout of classrooms is appealing. & 4.05 \\
Reliability & RL3: Sariputta College provides services at the scheduled time. & 4.05 \\
Responsiveness & RP1: The staff of Sariputta College can solve problems when they arise. \\
Empathy & E3: The lecturers of Sariputta College are sympathetic to the needs of students. & 4.16 \\
\hline
\end{tabular}

\section{Conclusions}

This research is to explore the factors influencing event the current situation of service quality in terms of reliability, responsiveness, assurance, empathy, and tangibles delivered to undergraduate students at Sariputta college, Muse, Shan State, the Republic of the union of 
Myanmar. Based on a quantitative approach, survey data were collected from 80 undergraduate students at Sariputta college and qualitative methods collected data or answers questions from 2 groups. The researcher, an adapted SERVQUAL instrument, for data collection and applied to the 5-element different independent variables and distributed structured questionnaire by applying Five-point Likert scale. Additionally, the five hypotheses are analyzed by using the SPSS Statistics software. Namely, descriptive statistics, Multiple Linear Regression, Cronbach's Alpha Results, ANOVAa, and coefficients.

The findings indicate that each of the five elements of service quality dimension by focusing on quantitative analysis showed that except tangible, reliability, responsiveness, assurance and empathy beta coefficient was positive and significant $(\mathrm{p}<0.005)$. The service performance in standardized coefficients (Beta). Expressly, tangibles variable had the strongest effect on overall service quality with the highest beta coefficient $(=-0.42)$ and with the significance level more than 0.05 , referred that tangible has no significance. Assurance variable has the lowest beta coefficient value $(0.061)$. and significant $(\mathrm{p}<0.007)$. The highest means value of a variable is Lecturers of Sariputta College have academic credentials of (4.44 percent) and the lowest means value of variables is the staff of Sariputta College being friendly toward students (3.49 percent).

Also, the qualitative technique showed that tangibles, reliability, responsiveness, assurance, and empathy are well-founded and can meaningfully perform. The primary stage of educational institution forms their service quality attitude of college. However, exploration results shows that in the current situation at College there are (1) less evaluation of the staff performance, (2) need facilities, (3) needs to provide new curriculum for the $21^{\text {st }}$ century skills and needs other for development books to improve their service performance living and stainable development that requires amelioration of the Sariputta college.

\subsection{Recommendation of the OD Intervention for the Future Collage Development}

Based on the research results there are still have many internal service performances to enhance to be consummated. Thus, the researcher recommended that to improve the lowest service quality at the same time to keep the highest service for the future. By covering more educations, it would fill the gap of service and make up for a deficiency to enhance their service quality delivery of the higher education at Sariputta College.

The qualitative result of this research showed that students enjoy services like teaching method, basic facilities and qualified teachers who graduated at the higher education level. However, they are least gratified with the services in the current condition. The empirical findings necessitate the college improve to better educational system for Sariputta, Muse a part of Myanmar educational system. The researcher recommends that Sariputta College should provide and deliver services based on students' desires and suggestion such as:

a. Need for organizing conferences, workshop, seminar, debate session, and talk show,

b. To evaluate staffs' performance on works,

c. To give students chance to choose their topics for assignments

d. To provide e-library for the progress of self-study and to have more reference books and other development books,

e. To upgrade the English language speaking, necessary equipment and to decrease the gap of service for sustainable development higher education system.

In addition, the researcher would like to recommend appropriate Organization Development intervention that can improve the service quality in terms of reliability, responsiveness, assurance, empathy, and tangibles at Sariputta College to change for the better improvement process. Moreover, the researcher would like to advice the College to apply more active logical, reasonable role service and to establish opportunities for virtual mobility with standard institutions. Next, the researcher would like to recommend SWOTAR on service quality to 
determine their underlying causes and these formulate an action arrange with reasoning and appreciative of the investigation from SWOTAR framework.

Undoubtedly, the above recommendations will be road map for change and development by shedding light on the most meaningful service features. These recommendations will improve the quality at Sariputta College, to change better service. Additionally, based on in this research, the researcher developed the recommendations of ODI, which is following in table 9.

Table 9.

Recommendations of the Organization Development (OD) Intervention for Future College Development

\begin{tabular}{|c|c|c|}
\hline Finding of Research & $\begin{array}{l}\text { Proposed Organization } \\
\text { Development Intervention }\end{array}$ & Expected Future Outcome \\
\hline $\begin{array}{l}\text { Lack of evaluation of college } \\
\text { ranking system on service work }\end{array}$ & $\begin{array}{l}\text { To evaluate of the college ranking } \\
\text { system on servicer work }\end{array}$ & $\begin{array}{l}\text { The college of a ranking system on } \\
\text { service work will improve and } \\
\text { academic credibility. }\end{array}$ \\
\hline $\begin{array}{l}\text { Less of reference books other } \\
\text { technical supports for } 21^{\text {st }} \text {-century } \\
\text { educational need. }\end{array}$ & $\begin{array}{l}\text { To provide the technical support } \\
\text { for } 21^{\text {st }} \text {-century educational need. }\end{array}$ & $\begin{array}{l}\text { Students will receive the technical } \\
\text { knowledge supports to } 21^{\text {st }} \text {-century } \\
\text { job }\end{array}$ \\
\hline Lack of staff training for service & $\begin{array}{l}\text { To offer staff training for the } \\
\text { service }\end{array}$ & $\begin{array}{l}\text { The staff of their performance will } \\
\text { improve and shed light on the most } \\
\text { meaningful service features. }\end{array}$ \\
\hline $\begin{array}{l}\text { Lack of English communication } \\
\text { and practice their speaking skill. }\end{array}$ & $\begin{array}{l}\text { To practice their English-speaking } \\
\text { skill to communicate }\end{array}$ & $\begin{array}{l}\text { Both staff and students will } \\
\text { improve their communication skill } \\
\text { in English }\end{array}$ \\
\hline $\begin{array}{l}\text { Lack of seminar and debate } \\
\text { sessions, talk show, conferences, } \\
\text { and workshop }\end{array}$ & $\begin{array}{l}\text { To organize the seminar, debate } \\
\text { sessions, and talks show, } \\
\text { conference, and workshop }\end{array}$ & $\begin{array}{l}\text { Students will improve their skills } \\
\text { and general knowledge. The } \\
\text { collage image will improve. }\end{array}$ \\
\hline $\begin{array}{l}\text { The staff lack of skills to } \\
\text { solve problems when they arise. }\end{array}$ & To practice problem solving skill & $\begin{array}{l}\text { The staff will improve their } \\
\text { problem-solving skills }\end{array}$ \\
\hline
\end{tabular}

\section{Acknowledgment}

The completion of this study has become one of the most unforgettable and cherished experiences in my profession. I would like to take this chance to express my heartfelt thanks and honest words of appreciation to those people whose helped, for their encouragement and for being a participant in this research project. First of all, I would like to say thank you from the bottom of my heart to Buddha, Dhamma, sangha, my parents, my mentor, and my benefactor. I would like to express my gratitude to my dedicated advisor Dr. Somchai Tantasanee who sacrificed valuable time for me, always gave me direction, useful comments, and helpful suggestions throughout the research process. In addition, for those who gave me a scholarship and are supporter, I would like to express my heartfelt gratitude to U Aung Myo Hain, Daw NiNi Thin Tun, Yangon, Myanmar and London Prospect Burma Foundation, UK. Lastly, I would like to record my thanks to all those men and women who gave me invaluable support while conducting this academic study. I will not forget the Sapienza University of Rome with whom I do my Oral- presentation for my International Conference on New Ideas in Management \& Economic and accounting committee.

\section{References}

Ahmad I, Nawaz MM, Usman A, Shaukat MZ, Ahmad N (2010). Impact of service quality on customer's satisfaction: empirical evidence from telecom sector of Pakistan. Interdisciplinary. Journal Contemp. Res. Bus., 1(12): 98-113.

Ahmad Z, Ahmed I, Nawaz MM, Usman A, Shaukat MZ, Ahmad N (2010). Impact of quality of short messaging service on customers Retention; an Empirical Study of Cellular Companies of Pakistan. Internet Journal Bus. Manage., 5(6): 154-160. 
Babakus, E. \& Boller, G.W. (1992) An empirical assessment of the SERVQUAL scale, Journal of Business Research, 24, pp. 253- 268.

Barnes, B. 2007. Analysing service quality: the case of post- graduate Chinese students, Total Quality Management and Business Excellence 18(3): 313-331.

Bitner, M.J. (1992), Servicescapes: The Impact of Physical Surroundings on Customers and Employees, Journal of Marketing, Vol. 56, pp.57-71

Carmen, J.M. (2000), "Patient Perceptions of Service Quality: Combining the Dimensions," Journal of Service Marketing, Vol.14, No.4, pp.337-352

Chase, R.B. (1978), "Where does the customer fit in a service operation?", Harvard Business Review, Vol. 56 No. 4, November-December, pp. 137-42.

Chong, Y.S. and Ahmed, P.K. (2012), "An empirical investigation of students' motivational impact upon university service quality perception: a self- determination perspective", Quality in Higher Education, Vol. 18 No. 1, pp. 37-41.

Cook, D.P., Goh, C. and Chung, C.H. (2002), "Service typologies: a state-of-the-art survey", Production and Operations Management, Vol. 8 No. 3, pp. 318-38.

Cooper, D. R., and Schindler, P. S. (2014). Business Research Methods. $12^{\text {th }}$ edition. New York: McGraw-Hill.

Dabholkar, P. A., D. I. Thorpe, and J. O. Rentz (1996). A measure of service quality for retail stores: Scale development and validation. Journal of the Academy of Marketing Science, 24(1), 3-16

Douglas, J., Douglas, A., \& Barnes, B. (2006). Measuring student satisfaction at a UK university. Quality Assurance in Education, 14(3), 251-267. doi: 10.1108/ 09684880610678568

Festus, O., Maxwell, K. H .,\& Godwin, F.U.,(2004), “Service Quality, Customer Satisfaction $\&$ Behavioral intensions in the service Factory", Journal of Service Marketing, Vol. 20 No. 1, pp. 59-72

Frazier, A. 1997. A roadmap for quality transformation in edu-cation. Boca Raton, Fla.: St. Lucie Press.

Frazier, A. 1997. A roadmap for quality transformation in education. Boca Raton, Fla.: St. Lucie Press.

Govender, J., Veerasamy, D., and Noel, D. (2014). The Service Quality Experience of International Students: The Case of a Selected Higher Education Institution in South Africa. Mediterranean Journal of Social Sciences, 5(8), 465-473.

Govender, K., and Ramroop, S. (2012). The relationship among the postgraduate research climate, service experience, quality and satisfaction. Ave African Journal of Business Management, 6(30), 8917-8926.

Gupta, A. \& Chen, I., (1995), "Service Quality: Implications for Management Development”, International Journal of Quality Management, Vol.12, No.7, pp.28-35.

Gupta, P., \& Kaushik, N. (2018). Dimensions of service quality in higher education - Critical review (stu- dents' perspective). International Journal of Educational Management, 32(4), 580-605.

Kotler Philip (2006), Marketing for Hospitality and Tourism, Pearson education, London. pP34-35, 59,420.

Krejcie, R.V and Morgan, D.W (1970) Determine Sample Size for Research Activities page 2. Retrieved on May 28, 2019 from https://snazlan.wordpress.com/tag/krejcie-morgan/ Article.PDF

Kwek, L.C., Lau, T.C. and Tan, H.P. (2010), "Education quality process model and its influence on students' perceived service quality", International Journal of Business and Management, Vol. 5 No. 8, pp. 154-165. 
La Londe B.J, M.C. Cooper and T.G. Noordewier, (1988) Customer Service: A Management Perspective, Council of Logistics Management, Journal of Transnational Management, 18, 101-129.

Lori S. C.(2003), "Exploring Linkages between Quality System, Service Quality, and Performance Excellences: Service Providers' Perspectives", Journal of Quality Management,

Lovelock, C. H. ,Wirtz J, Hean T. K. (2002). Services Marketing in Asia: Managing People, Technology and Strategy. Singapore: Prentice Hall.

Mahapanya (2017) Sariputta College, SCA-UK Newsletter (2017) Vol. 13.

Mamilla, R., Janardhana, G., and Anjan, B. G. (2013). Customer Satisfaction on Reliability Dimension of Service Quality in Indian Higher Education, International Journal of Industrial and Manufacturing Engineering, 7(12).

Manjunatha, K., \& Shivalingaiah, D. (2004). - Customer 's perception of service quality in librariesll. Annals of Library and Information Studies, 51(4), 145-151.

Marković, S. (2004). Measuring Service Quality in Croatian Hotel Industry: A Multivariate Statistical Analysis, Our Economy, 1/2: 27-35.

Marković, S. (2005). Perceived service quality measurement in tourism higher education: Case study of Croatia. Tourism Today, Fall: 91-109.

Marković, S. (2006). Expected Service Quality Measurement in Tourism Higher Education, Our Economy, 1/2: 86-95.

Marshall, G. \& Murdoch, I. (2003), "Service Quality in the Marketing of Consulting," Journal of Marketing, Vol.52

Mbise, E \& R.S.J Tuninga, R.S. J. (2013). The Application of SERVQUAL to Business Schools in an Emerging Market: The Case of Tanzania. Journal of Transnational Management, 18, 101-124.

Mbise, E and R. S.J. Tuninga (2012) Measuring Business Schools' Service Quality in an Emerging Market Using an Extended SERVQUAL Instrument, (University of the Netherlands, Heerlen, the Netherlands. College of Business Education, Dares-Salaam, Tanzania, 2012)

Miguel, P.A, Trota, A. N., Mendes, V., \& Amaral, P. (1998), “Assessment of Service Quality Dimension: A Study in a Vehicle Repair Service Chain”, Journal of Service Marketing, pp. $1-10$.

Mukesh Sharma, Pinki Dangi and Meenakshi Choudhary (2014) Actinomycetes: Source, Identification, and Their Applications. International Journal of Current Microbiology and Applied Sciences ISSN: 2319-7706 Volume 3 Number 2 (2014) pp. 801-832

Napitupulu, D., Rahim, R., Abdullah, D., Setiawan, M., Abdillah, L., Ahmar, A.,... \& Pranolo, A. (2018). Analysis of student satisfaction toward quality of service facility. Journal of Physics, IOP Publishing, 954 (1), p. 012019

Oliver, R. L. (1997). Satisfaction: A Behavioral Perspective on the Consumer. New York, NY: McGraw-Hill.

Oliver, R.L. (2009). A Cognitive Model of the Antecedents and Consequences of Satisfaction Decisions. Journal of Marketing Research, 17: 460-469.

Payne, A., (1995), Relationship marketing: a broadened view of marketing, in Payne, A. (Ed.), Advances in Relationship Marketing, Kogan Page, London.

Rafaeli, A., \& Sutton, R. I. 1989. The expression of emotion in organizational life. In L. L. Cummings \& B. M. Staw (Eds.), Research in organizational behavior, vol. 7: 1-37. Greenwich, CT: JAI Press.

Rafaeli, A., \& Sutton, R. I. 1990. Busy stores and demand- ing customers: How do they affect the display of positive emotion? Academy of Management Jour- nal, 33: 623-637 
Ramaswamy, R. (1996). Design and Management of Service Processes: Keeping Customers for Life. Reading, MA: Addison-Wesley Publishing Co.

Ransley, J., \& Ingram, H. (2001). What is "good" hotel design? Facilities, 19 (1/2), 79-86.

Sekaran, U., and Bougie, R. (2013). Research Methods for Business. West Sussex; Wiley.

Srikanthan, G. and Dalrymple, J. (2004) A synthesis of a quality management model for education in universities, International Journal of Educational Management, 18(4), 266 279.

Sultan, P, Wong HY (2012) Service quality in a higher education context: An integrated model. Asia Pacific J Mark Logits 24: 755-784.

Uppal, M. A., Ali, S., \& Gulliver, S. R. (2018). Factors deter- mining e-learning service quality. British Journal of Educational Technology, 49(3), 412-426. doi:10.1111/ bjet.2018.49. issue-3

Vanichbancha, K. (2003). Advanced statistical Analysis SPSS for windows Bangkok. Tammasam.

Wei, C. C., \& Ramalu, S. S. (2011). Students satisfac- tion with university: Does service quality matter? International Journal of Educational, 3(2), 1-15.

Wilson, A, Zeithaml V, Bitner M, Gremier D (2008). Services marketing: integrating customer focus across the firm. First European Edition. McGraw Hill, UK.

Zeithaml, V. A., Bitner, M. J., \&Gremler, D. D. (2008). Service marketing: Integrating customer focus across the firm (4th ed.). New York, NY: McGraw-Hill/Irwin.

Zeithaml, V.A. (2000). Service quality, profitability and the economic worth of customers: What we know and what we need to learn. Journal of the Academy of Marketing Science, 28(1), 67-

Zeithaml, V.A., Berry, L.L. and Parasuraman, A. (1996), "The behavioral consequences of service quality", Journal of Marketing, Vol. 60 No. 2, April, pp. 31-46.

Zeithaml, V.A., Parasuraman, A. and Malhotra, A. (2003). Service quality delivery through web sites: A critical review of extant knowledge. Journal of the Academy of Marketing Science, 30(4), 362- 375.

Zikmund, W. G., Babin, B. J., Carr, J. C., and Griffin, M. (2013). Business Research Methods. $9^{\text {th }}$ edition. Mason: South- Western/Cengage Learning. 